\title{
THE SCOR WORKING GROUP 21 INTERCOMPARISON OF RECORDING CURRENT METERS ON R/V «AKADEMIK KURCHATOV» - 50 YEARS LATER
}

\author{
Gould W. John ${ }^{1}$, Zenk W. ${ }^{2}$ \\ ${ }^{1}$ Emeritus Fellow, National Oceanography Centre, \\ Southampton, SO14 3ZH, UK, e-mail:wjg@noc.ac.uk \\ ${ }^{2}$ Senior Scientist, GEOMAR Helmholtz Centre for Ocean Research Kiel, \\ Düsternbrooker Weg 20, 24105 Kiel, Germany, \\ e-mail:wzenk@geomar.de \\ Submitted 25.06.2020, accepted 26.10.2020.
}

\begin{abstract}
This paper describes the activities of SCOR WG21 that carried out intercomparisons of moored, recording current meters in the late 1960s and early 1970s. The paper focusses particularly on the WG's involvement in the $7^{\text {th }}$ voyage of R/V "Akademik Kurchatov" and its participation in the ground-breaking Polygon-70 programme.
\end{abstract}

Keywords: current meter, mooring, Scientific Committee for Oceanic Research, WG21, POLYGON-70 Programme

\section{Introduction}

In the mid 1960s many of our observational techniques, for instance using water bottles and reversing thermometers, had changed little since the voyages of HMS "Challenger" (Wyville-Thompson and Murray, 1882-1895) and SMS "Gazelle" (Hydrogräphisches Amt der Admiralität, 1888) in the late $19^{\text {th }}$ century. During the late $1960 \mathrm{~s}$ and early 1970s, the advent of solid-state electronics and the ability for the first time to measure currents deep within the ocean using neutrally buoyant floats, (Swallow, 1955), and moored current meters (Richardson et al., 1963) were starting to open up new possibilities. Swallow's observations aboard R/V “Aries” in 1960 (Crease, 1962; Swallow, 1971) provided striking evidence that deep ocean currents are more energetic and variable than expected. This is now known as mesoscale variability and posed new challenges for oceanographic research.

The research in POLYGON-70 (Brekhovskikh et al., 1971) and the 1972 MidOcean Dynamics Experiment (MODE) (MODE Group, 1978) was at the start of two new directions of science and technology that were to develop enormously over the coming decades. The first was the use of recording current meters that could be deployed for months and eventually for years. The second was the exploration of the ocean mesoscale by using those long current meter records from arrays of moorings and from newer versions of Swallow's floats. (Koshlyakov, Monin, 1978). 
In this paper, the authors describe the work of the Scientific Committee for Oceanic Research (SCOR)'s Working Group 21 and, particularly, the WG's activities aboard RV "Akademik Kurchatov". They describe their personal memories of the voyage and their subsequent research relating to the use of current meters and the investigation of the oceans' mesoscale variability and global scale circulation.

\section{SCOR Working Group-21}

The involvement with POLYGON-70 was to allow Working Group 21 to carry out an intercomparison of different types of moored current meters. The Working Group was chaired by John Swallow ${ }^{1}$, with whom John Gould worked at the UK National Institute of Oceanography.

The aim of the Working Group was "To design and compose the means of carrying out an intercomparison at sea of the principal current measuring systems now employed for the continuous recording of current velocity on moored stations", (SCOR, 1966)2. These intercomparisons were designed to show how various designs of instruments responded to ocean variability so as to be able to compare and combine records and to know their accuracy. Some current meters used propellers that, by nature, were directional. Others used rotors that had a uniform directional response. The other concern was that the size of the directional vane sensor varied greatly between instruments and therefore had a wide range of response timescales. The early discussions of the group are described in SCOR (1970). The first intercomparison experiment was in August 1967 organised by Woods Hole Oceanographic Institution (WHOI) at their Site D on the continental slope aboard the little $(30 \mathrm{~m}) \mathrm{R} / \mathrm{V}$ "Gosnold". The instruments involved were Plessey MO21 (UK), Aanderaa RCM4 (Norway), Geodyne (USA) and the German designed and built Tiefenstrommesser. All the speed sensors were calibrated in a tow tank before the cruise. It had been planned that two scientists from the P.P. Shirshov Institute, (Kyrill Chekotillo and Boris Shekvatov), would join the intercomparison with Alekseev BPV2 instruments but, as was reported at the SCOR executive meeting in Warnemünde, DDR in October 1967, "Unfortunately at the last minute neither the USSR participants nor their Alekseev meters were available". Three moorings were laid on 16-17 July and recovered on 24 July.

Not all of the instruments worked perfectly, but after the analysis the WG concluded that another intercomparison would be needed to resolve the differences found in 1967. The report of the SCOR Executive meeting in August 1969 (SCOR, 1969) sets the context for the R/V "Akademik Kurchatov" exercise.

\footnotetext{
${ }^{1}$ Other members were Kyrill Chekotillo (PP Shirshov Institute, USSR), Nick Fofonoff (Woods Hole Oceanographic Institution, USA), Thor Kvinge, (Christian Michelson Institute, Bergen Norway), Boris Shekhvatov, (PP Shirshov Institute, USSR), Gerold Siedler (Institut für Meereskunde, Kiel, F.R.G.), and Ferris Webster (Woods Hole Oceanographic Institution, USA).

2 The SCOR Proceedings are available online in the Publications section of https://scor-int.org A summary of membership, terms of reference, at-sea intercomparisons and link to reports is available online at https://scor-int.org/group/21.
} 


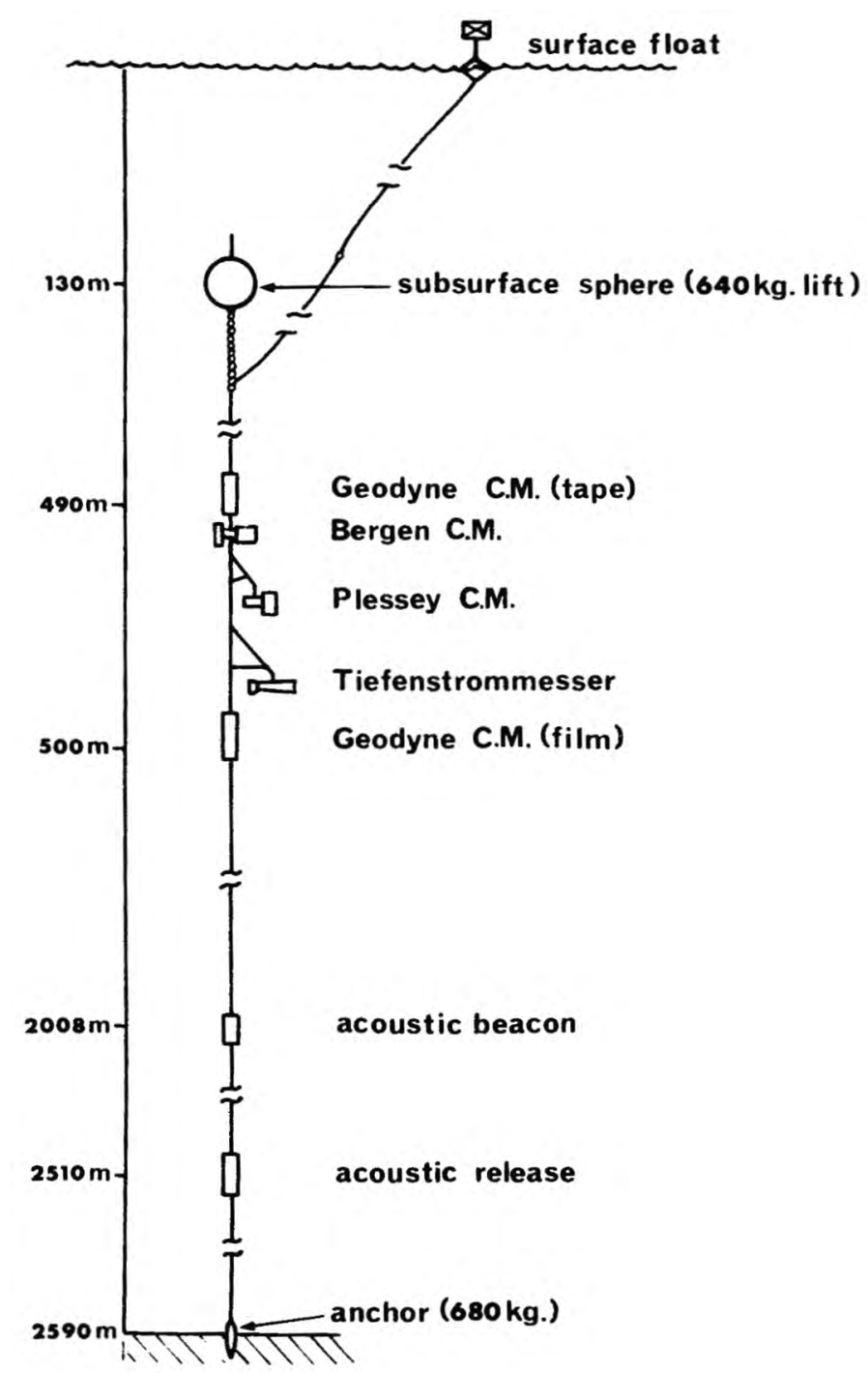

Figure 1. Mooring design used in the 1967 intercomparison. (Source SCOR WG21 report).

(Unless otherwise indicated illustrations are by the authors).

"The working group learned with great interest of the proposed expedition of the $R / V$ "Akademik Kurchatov" in early 1970, during which it was planned that a large number of Alekseev current meters will be moored in a small area in the trade-wind region of the Eastern North Atlantic. Dr. Chekotillo invited members of the working group to consider the possibility of participation in the expedition. It was unanimously agreed that this excellent opportunity for further intercomparison of current meters should not be missed. The working group invites the approval of SCOR for the proposal outlined below, and if such approval is forthcoming requests that SCOR should communicate its approval to the USSR Academy of Sciences.

It is proposed that three of each of the following types of current meters should be provided for inclusion in the array of Alekseev meters, for comparison over a period of about two weeks: Geodyne, Aanderaa, Plessey, Braincon. (Note:(1) It is unlikely that the new Hydrowerkstätten meters will be available before May 1970 (2) The group wishes to propose including Braincon meters in view of their extensive use by the Bedford Institute, Canada.) It is understood that it may be convenient for the $R / V$ "Akademik Kurchatov" to call at Southampton 
Gould W. John, Zenk W.

(UK) in mid-January 1970 to take equipment and visiting scientists on board, and might land the equipment there in April. It is proposed that the Geodyne and Braincon meters should be shipped to UK from Woods Hole and Bedford Institute. Aanderaa and Plessey meters, and possibly some Braincons, can be provided from UK sources. Although all members of the group would have wished to take part if possible, other commitments prevent Mr. Kvinge and Drs. Siedler and Swallow from doing so. Drs. Fofonoff and Webster hope to be able to participate, and suggest that Mr. R. Heinmiller (WHOI) be invited as well. Mr. W. J. Gould (UK, NIO) and Dr. W. Zenk (FRG, Kiel) are willing to take part and would take care of the Aanderaa and Plessey meters. Dr. Mann was unable to accept personally an invitation to participate, due to another seagoing commitment, but suggested that Mr. C.K. Ross and possibly one other from the Bedford Institute, Canada might be able to do so. It is proposed, therefore, that permission should be sought for the following six or seven visitors to join $R / V$ "Akademik Kurchatov" at Southampton in mid-January 1970: Dr. Fofonoff, Dr. Webster, Mr. Heinmiller (WHOI), Mr. Gould (NIO), Mr. Ross +1 other(BIO), Dr. Zenk (IfM, Kiel).

It is proposed that the six or seven visitors should leave at the first port after the 14-day moorings have been recovered, probably Dakar or Gibraltar in mid-February.'

During her $6^{\text {th }}$ voyage R/V "Akademik Kurchatov", the world's largest research vessel at the time, had visited Boston in October 1969 and been open to the public. The vessel had attracted large crowds. Participation in the SCOR intercomparison would present a first-hand opportunity to see the vessel and collaborate in Soviet marine science.

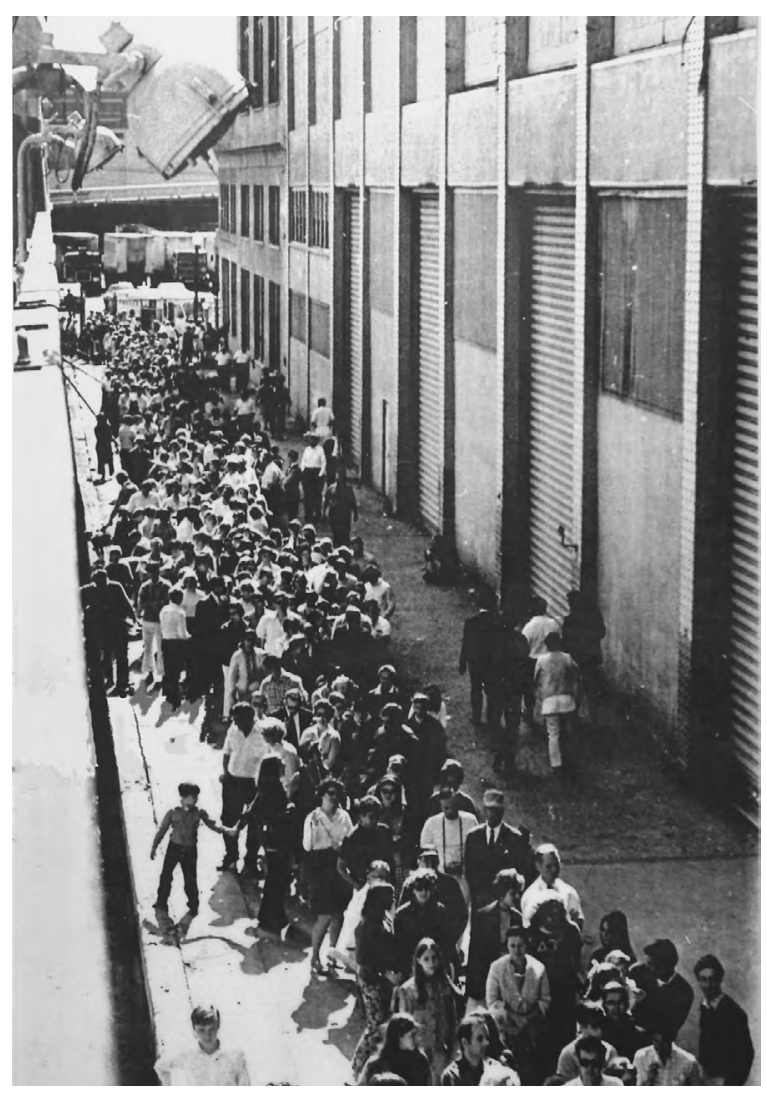

Figure 2. Crowds waiting to visit R/V "Akademik Kurchatov" in the Port of Boston, USA, in October 1969. (Image provided by Museum of the World Ocean, Kaliningrad, Russia). 


\section{The second intercomparison aboard R/V "Akademik Kurchatov"}

On March $7^{\text {th }} 1970$ five scientists ${ }^{3}$ and their equipment left Dove (UK) harbour on a small boat and sailed out to meet R/V "Akademik Kurchatov" and to take part in the intercomparison. Also joining the ship was Dr. Gilbert Jaffe, the Director of the US National Ocean Survey's National Oceanographic Instrumentation Center, Washington, DC who was there at the invitation of the Soviet Academy of Sciences. Ferris Webster also went out to the ship. As a member of the WG he went onboard to learn as much as he could about the plans for the cruise. We immediately learned that the chief scientist was Dr. Ivanov-Franskevitch, and that the main cruise objective was to make a detailed survey of the currents and water structure in an area of the southern North Atlantic near $15^{\circ} \mathrm{N} 35^{\circ} \mathrm{W}$. The moorings for the SCOR experiment were to be in addition to those of the array already laid by the sister ship of R/V "Akademik Kurchatov", R/V "Dmitriy Mendeleev". It was expected that SCOR participants would be on board for about 3 weeks. We also learned for the first time that two scientists from the Institute für Meereskunde, Warnemünde, DDR would take part in the intercomparison with their LSK instruments.

The passage southwards was spent learning about the Soviet mooring design. It had been known ahead of the cruise that the moorings used a continuous wire joining the anchor to the large surface buoy with a tall mast and radar reflector. The Soviet Alekseev instruments were attached to the wire with a triangular frame. A similar system was incorporated in the design of the Plessey instrument but the Aanderaa (also sometimes referred to as Bergen), Geodyne, Braincon current meters were normally coupled directly into the mooring line. Suitable brackets for these instruments had been constructed in the UK and on the passage south these were modified to fit the clamps usually used on Soviet moorings. A standard 15-minute sample rate was chosen for all instruments apart from the LSK, which took 10-minute samples. Two models of Alekseev were used, BPV-2 at 200 and $500 \mathrm{~m}$ and BPV-3 (with titanium cases) at $1000 \mathrm{~m}$.

The moorings were laid on 20 and 21 March at the corners of a 5-mile square centred on $16^{\circ} 33^{\prime} \mathrm{N}, 32^{\circ} 50^{\prime} \mathrm{W}$. Three moorings were recovered on 2 April (I, II and III). Mooring IV was recovered the following day.

Not all instruments produced good records for the entire period of the intercomparison but there was clearly enough data among the pairings to suggest that the experiment would produce useful results. The ship arrived in Monrovia, Liberia on April $7^{\text {th }}$ and the scientists who had boarded in Dover disembarked and flew home.

Copies of all the data records were sent to WHOI by the end of September and were processed and displayed using software developed by WHOI. Kyrill Chekatillo spent the period from mid-October 1970 to February 1971 at WHOI and was joined by John Gould and Don Lawrence for 2 weeks in mid-December during which time the data were analysed and the draft report produced.

${ }^{3}$ John Gould (UK), Walter Zenk (F.R.G.), Charlie Ross, Don Lawrence (Canada), Bob Heinmiller (USA). 
Gould W. John, Zenk W.

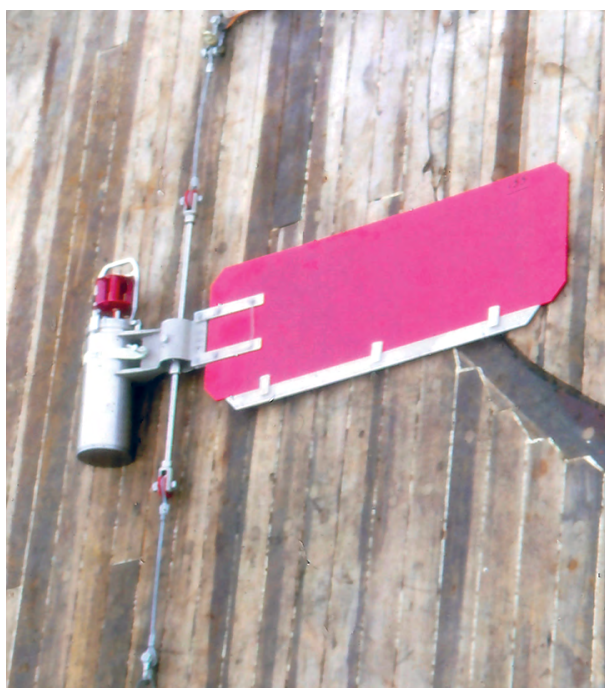

Aanderaa (Norway)

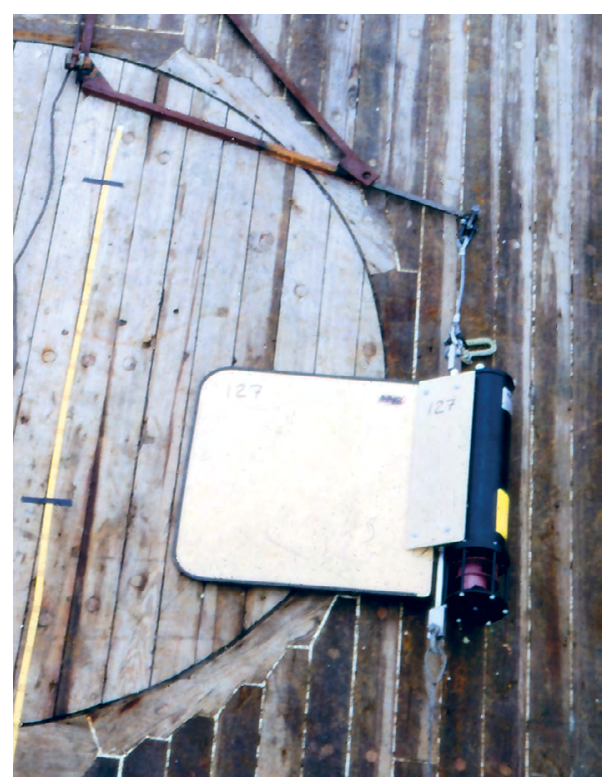

Braincon (USA)

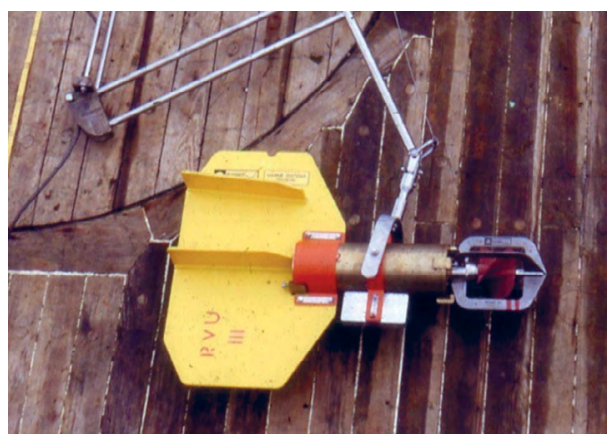

Plessey (UK)

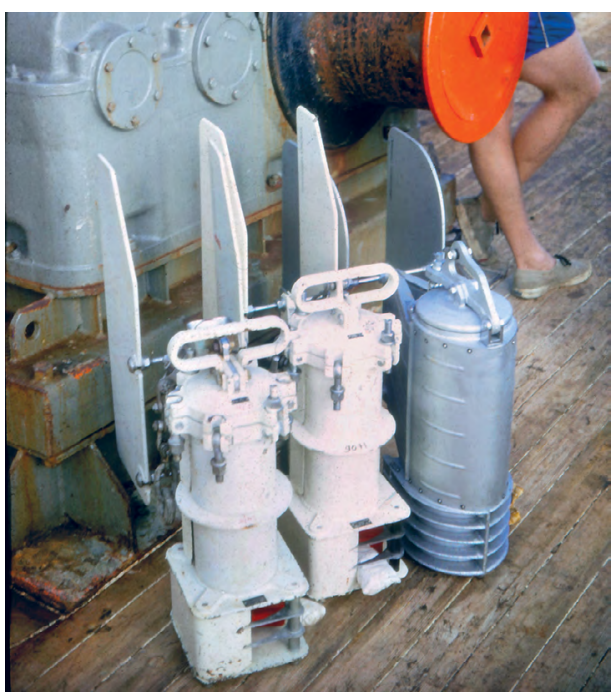

Alexeev BPV2 and BPV3 (Right) (USSR)

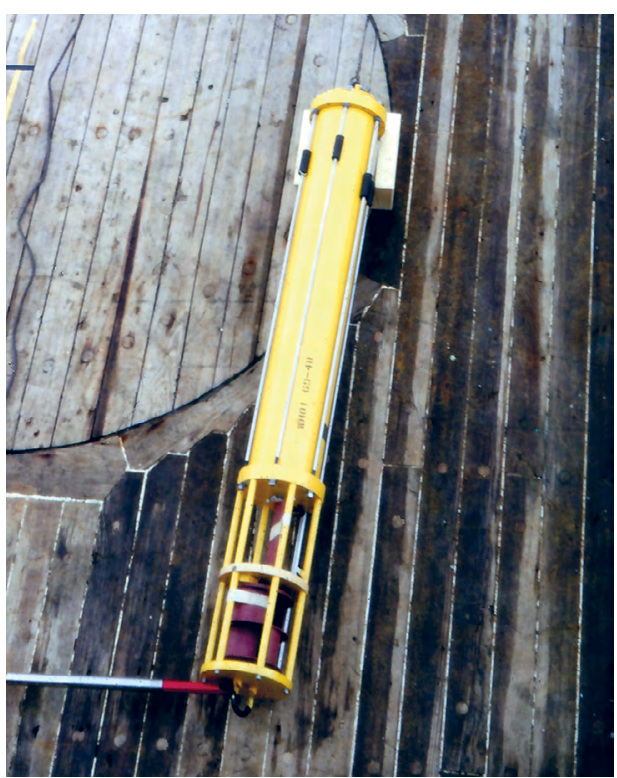

Geodyne (USA)

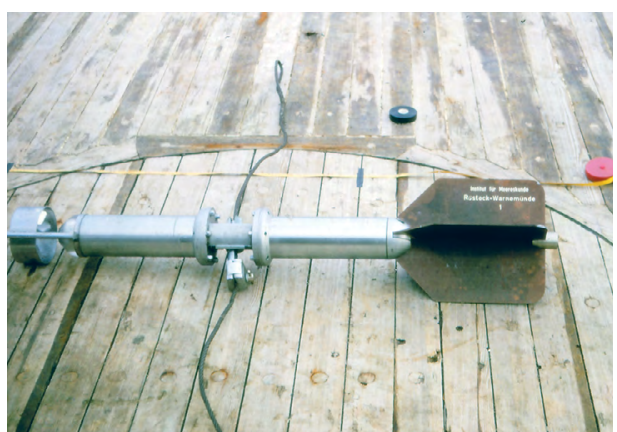

LSK (DDR)

Figure 3. The current meters used in the 1970 experiment and their country of origin. 

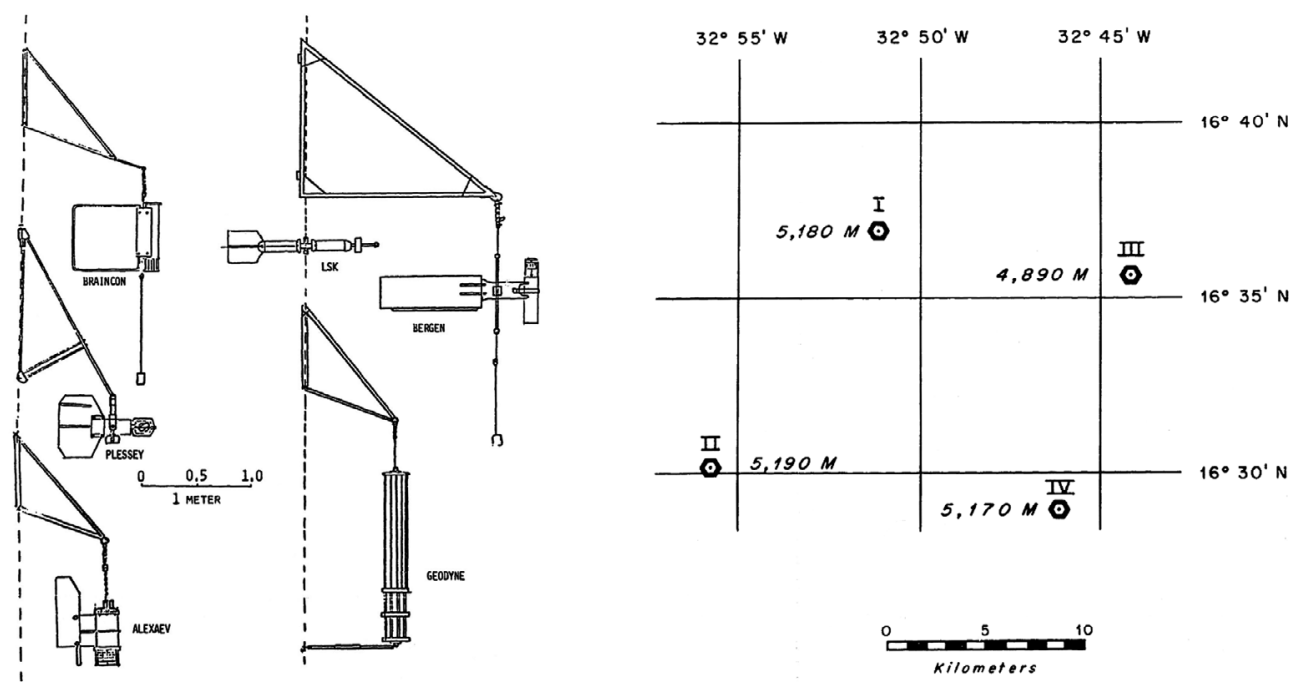

Figure 4. Left - Schematic of the current meters and their attachment to the mooring line.

Right - Mooring positions. (Images from SCOR WG21 report).

Table 1. The pairings and depths of the current meters.

\begin{tabular}{|c|c|c|c|c|}
\hline Depth $\mathrm{m}$ & Mooring I & Mooring II & Mooring III & Mooring IV \\
\hline 50 & $\begin{array}{c}\text { Aanderaa } \\
\text { Alekseev BPV-2 }\end{array}$ & $\begin{array}{c}\text { Plessey } \\
\text { Alekseev BPV-2 }\end{array}$ & $\begin{array}{c}\text { LSK } \\
\text { Alekseev BPV-2 } \\
\text { Braincon }\end{array}$ & $\begin{array}{c}\text { Alekseev BPV-2 } \\
\text { Geodyne }\end{array}$ \\
\hline 200 & $\begin{array}{c}\text { LSK } \\
\text { Geodyne } \\
\text { Alekseev BPV-2 }\end{array}$ & $\begin{array}{c}\text { Braincon } \\
\text { Alekseev BPV-2 }\end{array}$ & $\begin{array}{c}\text { Alekseev } \\
\text { Aanderaa BPV-2 }\end{array}$ & $\begin{array}{c}\text { LSK } \\
\text { Alekseev BPV-2 } \\
\text { Plessey }\end{array}$ \\
\hline 1000 & $\begin{array}{c}\text { Plessey } \\
\text { Alekseev BPV-3 }\end{array}$ & $\begin{array}{c}\text { LSK Aanderaa } \\
\text { Alekseev BPV-3 }\end{array}$ & $\begin{array}{c}\text { Alekseev BPV-3 } \\
\text { Geodyne }\end{array}$ & $\begin{array}{c}\text { Alekseev BPV-3 } \\
\text { Geodyne }\end{array}$ \\
\hline
\end{tabular}

It became clear immediately that there were significant performance differences between the instruments. Though all of them captured the overall direction of flow during the intercomparison period (within $6^{\circ}$ ), there were significant differences in the mean speeds measured - as revealed by the lengths of the progressive vector diagrams. The most obvious difference within pairings was in the vector variance of the records revealed graphically in the vector distribution plots that showed an absence of low speed readings particularly in the Braincon and Aanderaa instruments, both of which used rotor speed sensors and neither of which were deployed in their normal "in line" manner. The Plessey instruments showed this property to a lesser degree. The Geodyne instruments, though they also used a rotor speed sensor, did not exhibit a lack of low speeds. This was attributed to the instrument's small direction vane which was sampled every 5 seconds for 2.5 minutes and combined vectorially with the speed readings. This behaviour was not seen in the 1967 intercomparison on moorings with subsurface buoyancy.

The Alexeev records were not immune to problems. In particular they seemed to amplify variability (speeds were anomalously low during quiet periods and anomalously 

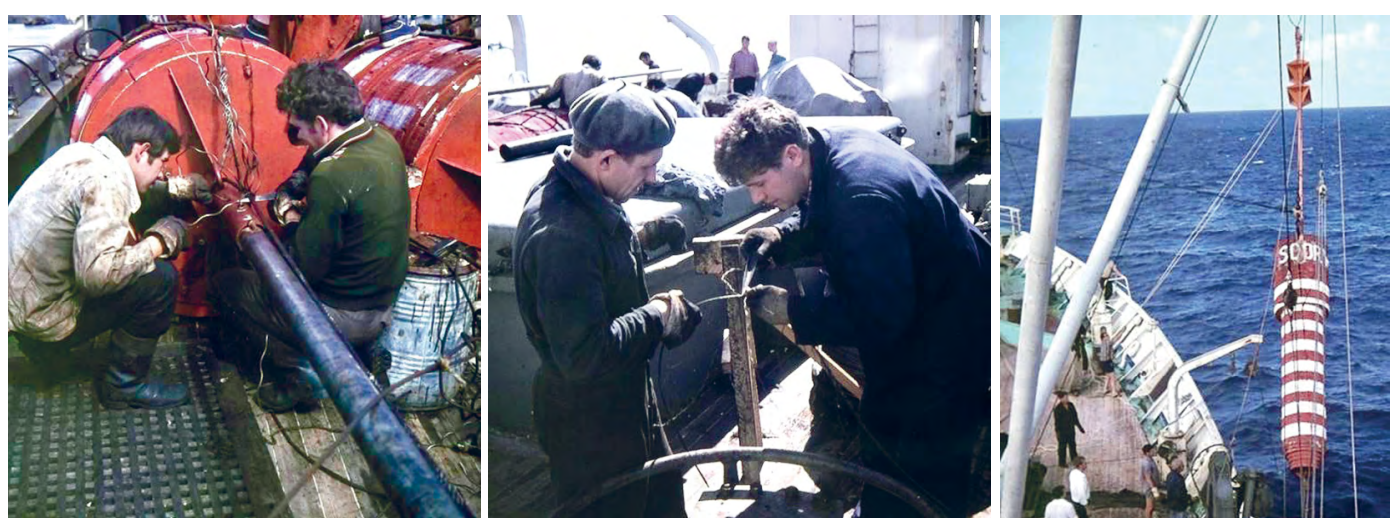

Figure 5. Preparation of mooring components. Left - Reinforcing the lower plate of the huge surface buoy. Centre - Assembling an attachment triangle for the different current meter types.

Right - One of the SCOR mooring buoys.

high when flows were energetic). The report went on to examine the spectra of the current meter records and the coherence vertically and horizontally.

The main conclusions were that overall the current meters all made good estimates of the long-term vector mean but noted that the agreement was largely fortuitous because of the underlying problems of speed and direction sensor response.

The most far-reaching conclusion was drawn from the outcome of both the 1967 and 1970 intercomparisons and is worth reporting verbatim here.

"It is recommended that users of moored current meters should study the effects of mooring design, and mounting of instruments, on the intensity of high frequency fluctuations and the consequences of such fluctuations in contaminating records obtained should also be studied."

\section{SCOR WG 21 after POLYGON-70}

There were a number of subsequent meetings of the WG at which it was discussed how to resolve the differences revealed by the R/V "Akademik Kurchatov" experiment. There was also a recommendation for an intercomparison experiment in shallow water though this was not carried out. A third intercomparison was done in August 1972 at Woods Hole Site D. John Gould and Kyrill Chekatillo took part, as did Anatoly Suslyaev of the Shirshov Institute. The experiment involved Alekseev, LSK, Geodyne model 850 (as used on R/V “Akademik Kurchatov") and VACM 4 (Vector Averaging Current Meter, AMF, USA) on surface and subsurface moorings. The moorings were only $400 \mathrm{~m}$ apart (they had been planned to be $1 \mathrm{~km}$ apart) with instrument groups at 50,200 and $1000 \mathrm{~m}$ on the surface mooring and at 160 and $1000 \mathrm{~m}$ on the subsurface buoy. All the instruments were attached to the moorings in the manner in which they were designed to operate. The experiment lasted from 22 August to 4 September during which time a tropical storm

\footnotetext{
${ }^{4}$ The VACM as designed to convert frequently sampled speed and direction (8 samples for each revolution of the rotor) that are summed as north and east components, thus eliminating the issue of mismatch of the time response of the rotor and vane. This is known as "burst sampling".
} 
passed near the moorings with wind speeds reaching $20 \mathrm{~m} / \mathrm{s}$ near the end of the intercomparison period. Telemetry showed that the moorings did tangle for a short while but separated with no damage.

The results showed that on the subsurface mooring all paired instruments agreed very closely whereas on the surface mooring there was clear evidence that the Alekseev and Geodyne instruments had anomalously high energy at high frequencies and this finding explained the discrepancies between instruments during the R/V "Akademik Kurchatov" experiment.

This finding was confirmed subsequently by comparisons made by Gould and Sambuco, (1974) who compared earlier WHOI measurements using Geodyne instruments on surface and subsurface moorings.

\section{Personal R/V "Akademik Kurchatov" memories}

It is hard to remember the world 50 years ago. John Gould was 27 and had been working with Dr. John Swallow at the National Institute of Oceanography (NIO) for only three years, learning how to operate moored current meters (Aanderaa, Braincon and Plessey) and how to deploy and track neutrally buoyant floats. John Gould knew more about recent Russian music (Stravinsky and Shostakovich) than about Soviet oceanography since almost all papers were in Russian. Walter Zenk is three years older. After finishing his study of electrical engineering at the Technical University in Aachen (RWTH) he had already gained his doctorate in oceanography with Prof. Günter Dietrich. He worked as a research scientist with Prof. Gerold Siedler (a member of WG21) in the physical oceanography department of the Institut für Meereskunde (IfM) in Kiel. His first cruise on the, then new, FS "Meteor" took place in early 1967 where he collected and later analysed continuous hydrographic profiles and moored current meter data from the Mediterranean outflow west of the Straits of Gibraltar. He was interested to see on R/V "Akademik Kurchatov" in 1970 that Russian colleagues under the leadership of Academician K.N. Fedorov had their own conductivity-temperature-depth (CTD) profiler (AIST) operated on a single-conductor cable and that for backup and calibration, all CTD profiles were accompanied by classical hydrographic bottle and reversing thermometer samples, exactly as Walter Zenk had experienced on FS "Meteor" three years earlier.

Both John Gould and Walter Zenk had limited experience of foreign travel. John Gould had been on holidays by car to Germany and France, and to conferences in Berne and Dublin. Walter Zenk had his first contact with sea-going research on a student cruise with the research cutter "Alkor" to the Skagerrak and off Norway with Prof. Dietrich. A trip on the "Alkor" would quickly reveal whether someone was really "seaworthy" and not prone to seasickness. Unfortunately, Walter Zenk did not belong to this elite group of observational oceanographers. It was in Dublin at the ICES symposium on ocean variability in late September 1969 that John Gould first learned about his possible involvement in the R/V "Akademik Kurchatov" experiment - on a Soviet ship! 

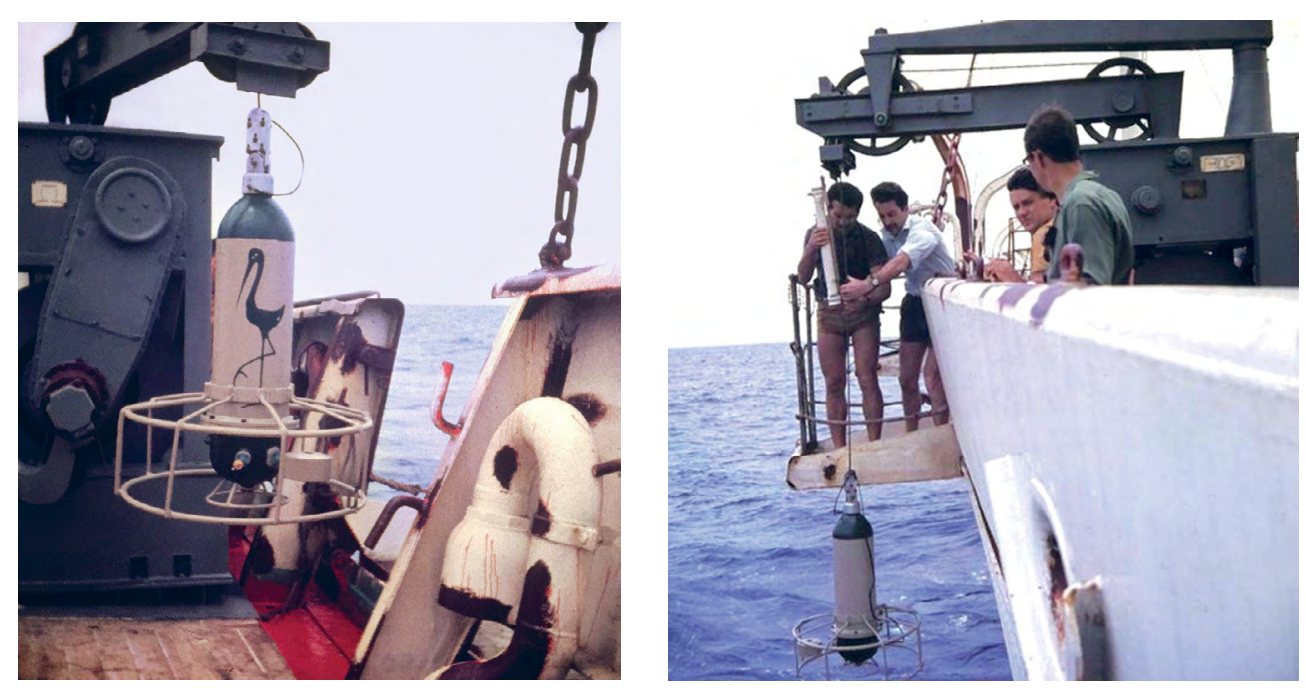

Figure 6. The AIST (Stork) CTD aboard R/V “Akademik Kurchatov” and being deployed with a watersample bottle (Right) (Photographs by the authors).

Our knowledge of the Soviet Union had come from the western media and we knew of its space technology - Sputnik, Laika, Yuri Gagarin. However we knew little about Soviet marine science and technology - except that for us the subject was "oceanography" and for them, "oceanology".

For German citizens the post-war division of their country was a stark fact that made bilateral scientific cooperation between the "two Germanys" very difficult if not impossible. Only formal high-level exchanges through international bodies like SCOR made blue water oceanographic collaboration between the two states possible.

The practical organisation of the SCOR intercomparison aboard R/V "Akademik Kurchatov" was challenging and mostly arranged by John Swallow and the NIO administration. In short, we had to get the American equipment and people, Bob Heinmiller and George Tupper (who would help set up the Geodyne current meters), the Canadians (Charlie Ross and Don Lawrence) and Walter Zenk from Kiel to the UK in time to join the ship. Walter had hoped he could embark as R/V "Akademik Kurchatov" passed through the Kiel Canal but was told that this would not be possible. In any case when was the ship going to arrive? The original plan was for late January 1970, but the NIO started to receive regular telegrams (to its telegraphic address, OCEANS WORMLEY) from the Shirshov Institute (John Gould thinks via the Soviet Embassy in London) telling us that the sailing was delayed because of severe ice conditions in the Baltic Sea. Spring of that year was a bad season as documented by Löptien and Dietze (2014).

Eventually we decided that the Americans and Canadians should come to NIO and wait. They stayed in the $16^{\text {th }}$ Century White Hart Inn which was very pretty, though it was not very well heated. We all had the required vaccinations and a Senegalese visa in our passports for our expected return from Dakar. Week followed week with further delays announced and then in late February a message to say we might land in Liberia - so we had to get new visas. At last, we received word that R/V "Akademik Kurchatov" would be passing Dover (not Southampton as originally planned) on March $7^{\text {th }}$. 

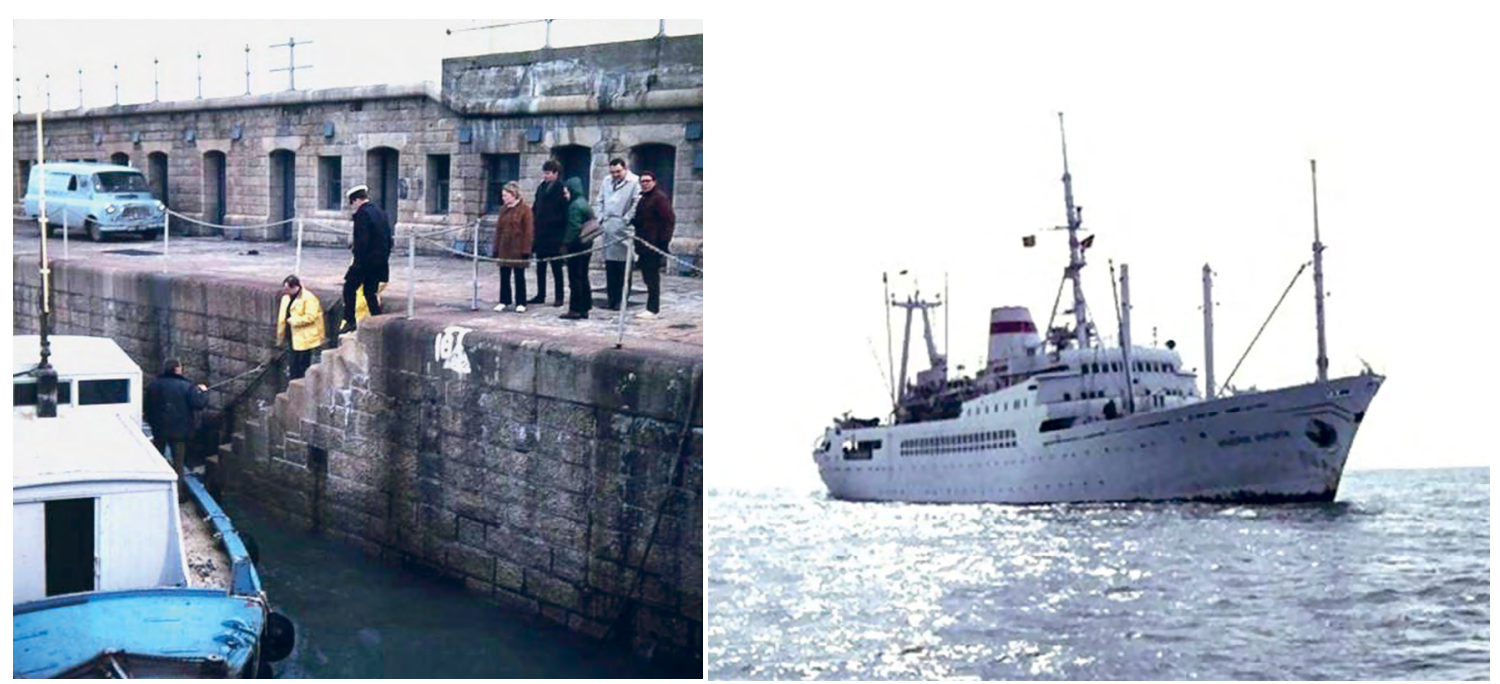

Figure 7. Left - Embarking in Dover. Right - R/V “Akademik Kurchatov" appears out of the mist.

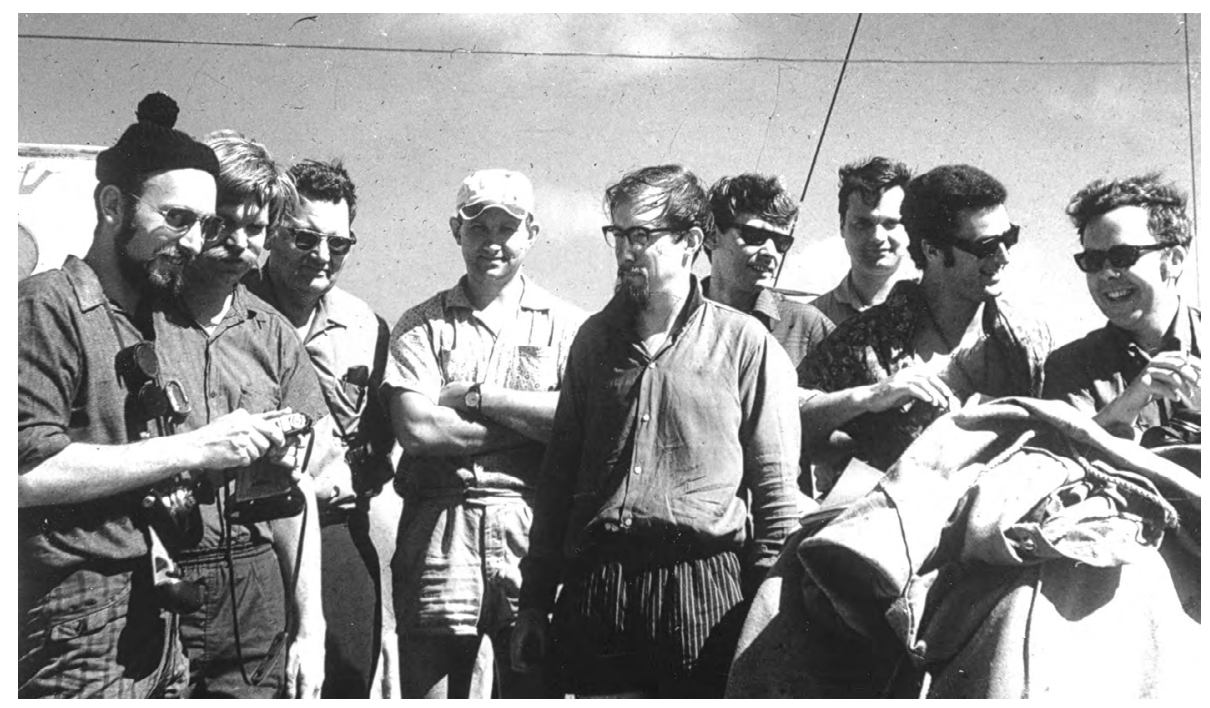

Figure 8. The SCOR WG 21 scientists. L to R Walter Zenk, Bob Heinmiller, Gilbert Jaffe, Kyrill Chekatillo, John Gould, Don Lawrence, Eberhard Francke, Günter Plüschke, Charlie Ross.

(Photograph from by R/V "Akademik Kurchatov" photographer).

So, off we set to on the 100 mile journey to Dover by car and with the equipment in the NIO's lorry. On the quayside we met for the first time Gil Jaffe there at the invitation of the Soviet Academy of Sciences as an observer. Even before we sailed we were reminded how different this trip was to be. Walter Zenk remembers clearing UK customs at the ferry terminal in Dover and the officer's surprised face when he checked the disembarkation card and saw far-off Africa as the destination instead of the usual Ostende or Calais.

We sailed off in a little pilot boat to meet the huge $(141 \mathrm{~m})$ white R/V "Akademik Kurchatov" which appeared from the east through the mist on that cold spring day. A door opened in the side and first Ferris Webster boarded to learn as much as he could about the plans then we and the equipment followed. Soon Ferris left, the door closed and our adventure started. The first surprise was to learn of the participation of scientists from the 
IfM in Warnemünde. For Walter Zenk, Eberhard Franke and Günther Plüschke were the first people he had ever met from the DDR, "the other" Germany. It was an overwhelming experience. They were in charge of the LSK current meters, which we discovered was a high-precision instrument built in their lab in Warnemünde totally independent of western components and tools. Today it is hard to realize the separation of the two Germanys. To most marine scientists in Kiel, Boston and Woods Hole on the other side of the Atlantic Ocean seemed closer than Warnemünde only $200 \mathrm{~km}$ to the Southeast. E. Francke et al. (1977) wrote a summary of the intercomparison in the IfM Warnemünde journal.

Neither of us kept a diary but instead we can best describe the voyage in a series of impressions - many that were novel or strange.

Food and drink. We ate well, though there were many new dishes and experiences: Kvass, beer made from stale bread and what we referred to as "Georgian crushed chicken" cooked on the stove top under a heavy weight that broke the bones. Lots of pickled vegetables - not John Gould's favourite. The traditional Russian home-style meals were served by skilled waitresses punctually as on all ships. "Sailors' Sundays" on Thursdays with cake in the afternoon were a routine familiar to Walter Zenk but not to John Gould.

John Gould was surprised that everyone did not eat in the same dining room (mess). On UK ships scientists, technicians and officers all ate together and the crew ate separately but he had expected a more egalitarian system. Vodka and toasts were a different way of drinking and even the large quantities didn't seem to give you a hangover. It was good training for later involvement with Scandinavian scientists in the ICES Oceanic Hydrography Working Group where there were plenty of toasts.

Women at sea. There were a few women scientists on western ships but at that time no crew members. R/V "Akademik Kurchatov" was different and the effort to give them all a free day on International Women's day when all ladies were served by their male colleagues independent of their social or maritime status highlighted the difference.
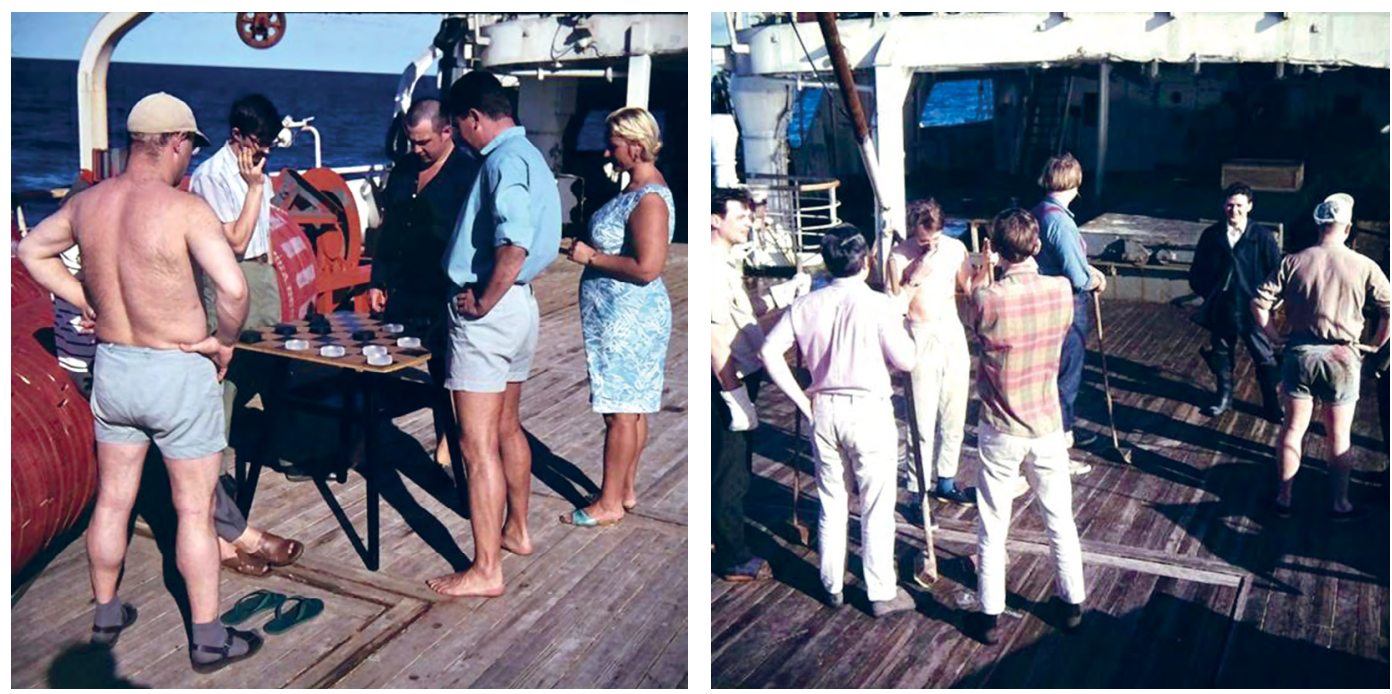

Figure 9. Left - Crew playing draughts. Right - SCOR scientists prepare to clean the decks under the leadership of Academician Konstantin Fedorov (Dark Jacket). 

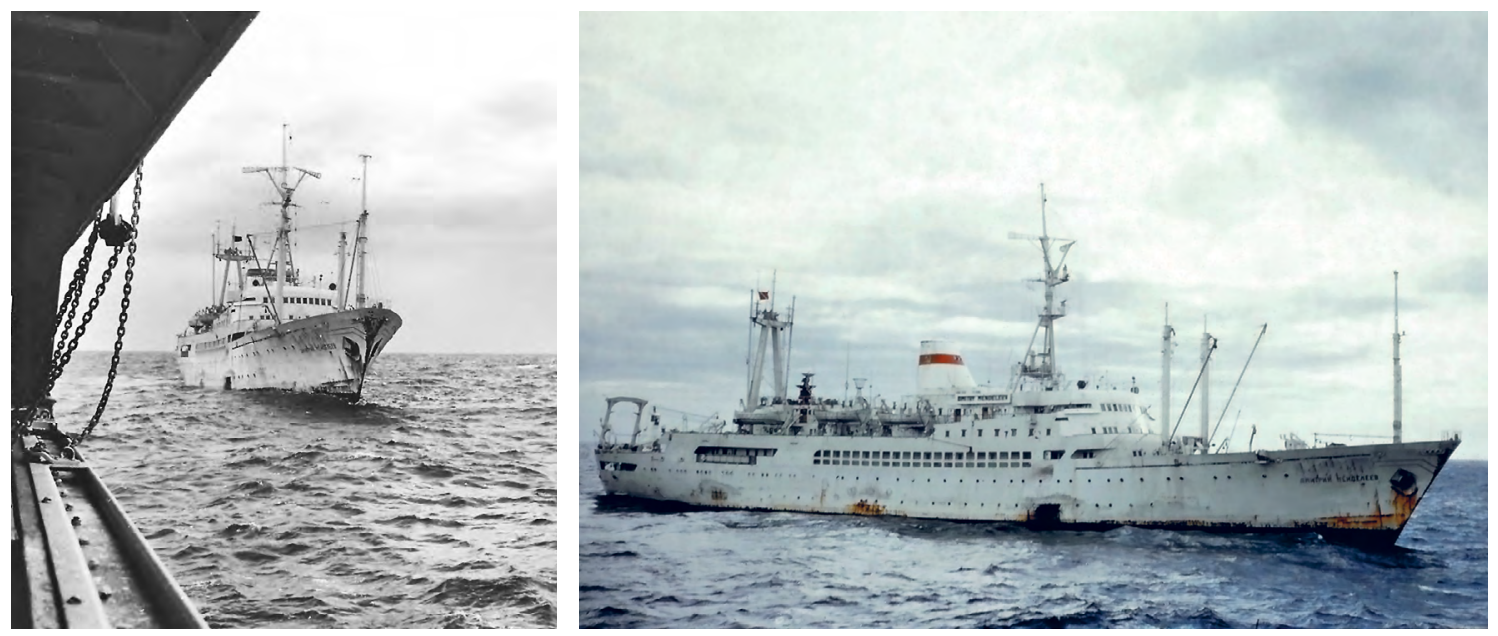

Figure 10. Meeting with sister ship R/V “Dmitry Mendeleev”.

Films. Just as on our ships, "Film night" was a pleasant interlude but there seemed to be a lot of war films.

Meeting other ships at sea. We had never been on ships where there were transfers of people and equipment between ships at sea. This seemed to happen quite often and was often an excuse for a party.

Announcements. The loudspeakers in the labs and cabins woke us cheerily each morning at 0700 and seemed to be talking to us continuously throughout each day.

Echo sounding. On our ships the echo sounder was central to everything we did and all cruises collected soundings routinely. We never saw an echosounder on R/V "Akademik Kurchatov".

Teaching English. As a real "Englishman" John Gould was asked if he would give English lessons. He had never realised until then what a complicated language English is. For every rule there are ten exceptions.

Living in a bubble. Our SCOR WG21 work was embedded in the wider operation of Polygon-70. We realised that it was a big exercise because of all the other ships we met but we think it was not until the mid 1970s that we discovered that POLYGON-70 was a Soviet exercise to explore the oceanic thermohaline finestructure (Fedorov, 1976) and mesoscale (Koshlyakov, Monin, 1978).

Mooring work. The hardware was very different - huge surface buoys, continuous (ungalvanized) wire, relatively small anchors, having to solve the practical problems of attaching various types of instruments, deployment over a davit rather than an A frame from considerable height, surprise at the wide range of recording media (magnetic tape, photographic film, printed paper), first time we had seen the use of titanium (in the BPV-3 pressure cases) See Figure 3.

Hospitality and friendship. We were made very welcome and came home with suitcases full of badges, flags, postcards and bottles of Armenian brandy. We had come ill-prepared to reciprocate, though Bob Heinmiller left several pairs of true American blue jeans on board. 

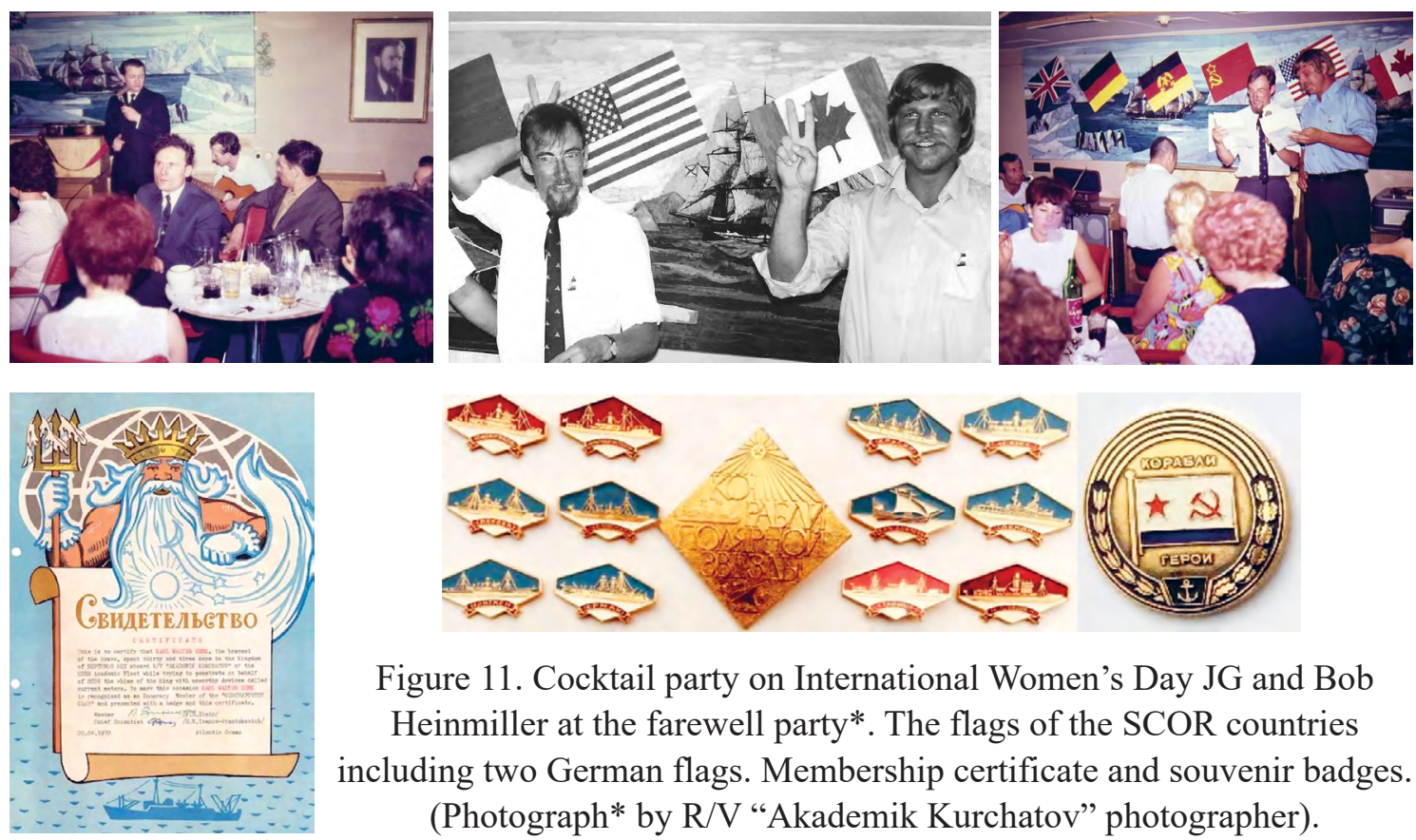

Figure 11. Cocktail party on International Women's Day JG and Bob Heinmiller at the farewell party*. The flags of the SCOR countries including two German flags. Membership certificate and souvenir badges.

(Photograph* by R/V “Akademik Kurchatov” photographer).

The farewell party a few days before landing in Monrovia was memorable. In the morning all of us were part of the thorough cleaning of the decks. In the evening the huge mess room was decorated with the all our national flags and of course two for Germany. The Captain elected his international guests to membership in the elite "Akademik Kurchatov Club" and we all accepted our certificate decorated with Neptune and his Trident. (Figure 11).

So finally, it was time to leave R/V "Akademik Kurchatov", in Monrovia - a surprise to most of us on board as we had expected to leave in Dakar and we were eager to send telegrams to warn of our return. For Walter Zenk, sending news of the plans for his return was particularly important since he was to get married to Maren in early May. In the middle of the cruise he wrote a short telegram including the estimated
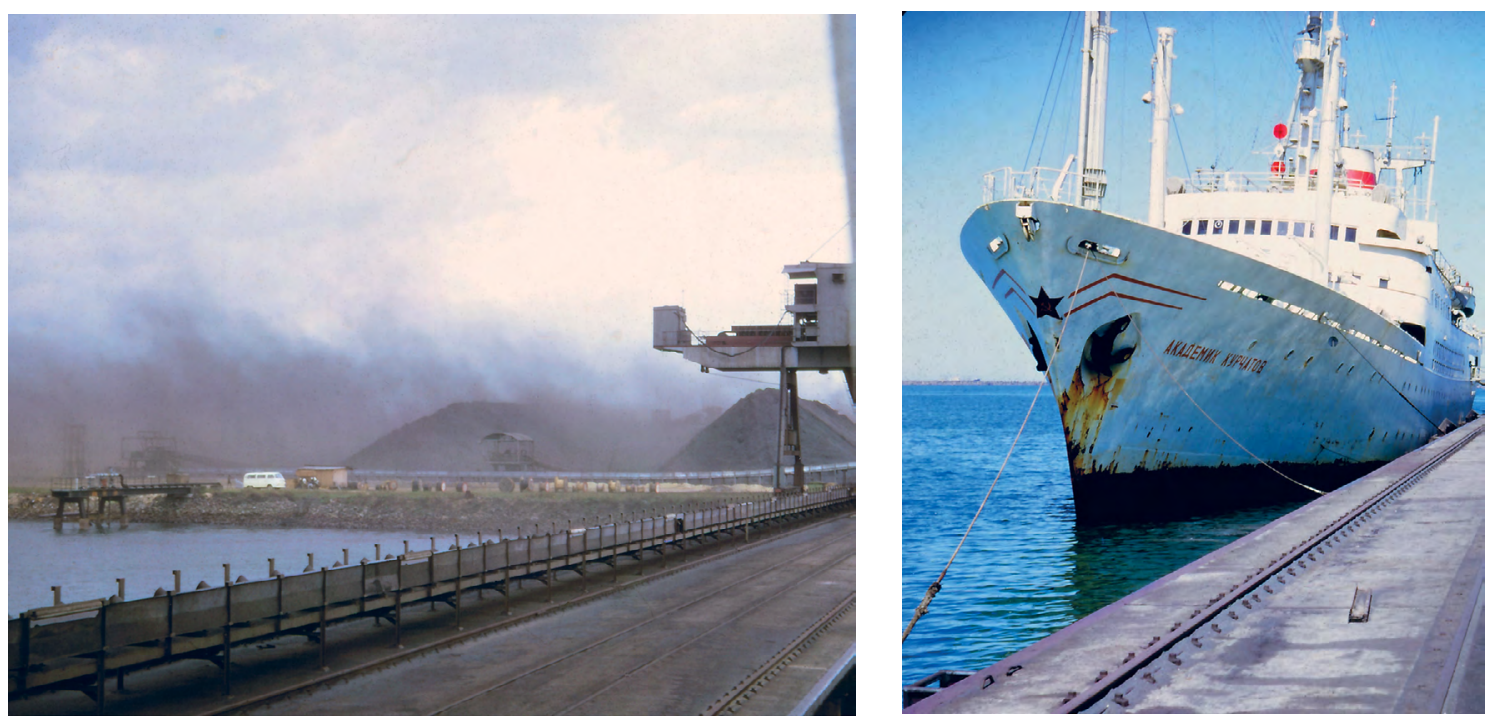

Figure 12. Left - The Monrovia iron ore mountain; Right - Farewell to R/V “Akademik Kurchatov". 
time of arrival (ETA) in Monrovia and delivered it to the radio operator. However, the ship's Captain had, without telling Walter Zenk, deleted the information about where the cruise would end. The shortened message caused tremendous confusion and some anxiety in Kiel.

This was to be our first experience of Africa. As was usual with research ships we docked a long way from town so the walk to find a bar and some local food (John Gould seems to remember having a buffalo burger) - it seemed that everyone in a position of authority spoke with an American accent and there was an enormous dusty mountain of iron ore ready for export. We had been longer at sea than we (or our colleagues and relations at home) had expected so we were eager to get flights. John Gould's was with UTA via Paris (le Bourget) to London. The plane left after midnight so it was a dark 35-mile taxi ride into the unknown until a few lights appeared in the distance. He remembers clearly seeing the plane's landing lights en route appearing out of the humid African night and then up the boarding steps and into a different world.

And so eventually he arrived at London Heathrow and was, for the only time in his life stopped by the customs official. He must have looked very suntanned, had lost weight and had a beard - very suspicious!

Customs - "Which flight have you arrived on?"

John Gould - "From Paris"

Customs - "What were you doing in Paris?"

John Gould - "I was en route from Liberia"

Customs _ " "What were you doing in Liberia?"

John Gould - "I had left a ship"

Customs - "What ship was that?"

John Gould - "A Soviet research ship"

Customs - "Where did you join the ship?"

John Gould - "Dover"

Customs - "Please open your case".

There were lots of souvenirs from R/V "Akademik Kurchatov" to support my story and nothing illegal and so out I went to find that my wife Hilary had been waiting there for hours. The adventure was over but after 50 years the memories are still vivid. Walter Zenk being an employee in public service had to wait for two days in Dakar for the next Lufthansa flight further delaying his homecoming. The edited telegram and its consequences are an often-repeated anecdote in the Zenk family and particularly in May 2020 at their $50^{\text {th }}$ wedding anniversary celebrations.

\section{Our science after R/V "Akademik Kurchatov"}

After our adventure on R/V "Akademik Kurchatov", we returned to our research each of us contributing to both developing better and longer current meter records and also to addressing the wider objective of POLYGON-70, learning more about the oceans' thermohaline fine structure and mesoscale variability. 
John Gould analysed long current meter records collected from the NE Atlantic and in particular focussed on their ability to reveal details of the internal wave spectrum, later corresponding with Konstantin Sabinin, a world leader in the field. He was awarded his Doctorate in late 1971 and then spent 1972 at WHOI, taking part in and analysing the third WG21 intercomparison but also analysing WHOI's past records from surface and subsurface moorings and thus reinforcing the SCOR findings (Gould, Sambuco, 1972). While he was in Woods Hole planning was underway for the US/UK Mid-Ocean Dynamics Experiment (MODE) and he took part in the experiment aboard the RRS (Royal Research Ship) "Discovery" making him the only person to have taken part in the fieldwork of MODE and POLYGON-70. He particularly analysed the current meter and float data using objective analysis to map the flow field (Freeland, Gould, 1976).

From 1965 on, continuously measuring CTD probes enabled totally new insights into oceanic fine structures. The marine physics department of IfM Kiel was among the first groups to discuss the newly detected thermohaline "staircase" below the Mediterranean Outflow layer in the Northeast Atlantic (Siedler, Zenk, 1981). Main results entered the unique monograph about fine structure in the world ocean by Academician K.N. Fedorov (1976), who was a major participant in the POLYGON-70 voyage of R/V "Akademik Kurchatov" when Walter Zenk had the opportunity to meet him for the first time. Both John Gould and Walter Zenk along with other members of SCOR WG21 (Fofonoff, Siedler, Swallow and Webster) were co-authors of the main publication from MODE (MODE Group, 1976).

After POLYGON-70 and MODE the US/USSR POLYMODE collaboration explored the wider distribution of mesoscale variability. (Bob Heinmiller became executive manager of POLYMODE and an earlier innovator of electronic communication, Kubany, 2008). In parallel, European countries deployed both floats and current meters to explore the mesoscale in the NE Atlantic in the North East Atlantic Dynamic Study (NEADS). This revealed new features of the mean circulation and variability (Dickson et al., 1982; Dickson et al., 1985). There were also new revelations about frontal structures south of the Azores (Gould, 1985). The ability to collect current meter records for as long as a year through painstaking engineering trials such as those at Woods Hole Site D (Heinmiller, 1976) allowed us to start to quantify components of the global scale mean circulation. For example, a subsurface current meter mooring at the Shag Rocks Passage measured the permanent overflow of Antarctic bottom water across the deepest sill of the Scotia Ridge at the southern rim of the Argentinean Basin (Zenk, 1981). The Kiel mooring 276 site in the Azores Basin has been maintained continuously since 1980 (Siedler et al., 2005).

We started to realise the wide variety of eddy-like structures and Walter Zenk explored the mesoscale salt lenses of Mediterranean Water in the Atlantic (Armi, Zenk, 1984). McDowell and Rossby (1978) used the name "Meddy" for these baroclinic species in the ever-expanding eddy zoo (Stommel et al., 1977). Meddies were found to substantially influence the shape of the Mediterranean Water tongue, acting as salinity sources far from their origin in the Gulf of Cadiz. Many years later our Russian colleagues D.Y. Mikhin and O.A. Godin (1997), studied the acoustic effect of drifting meddies from a theoretical standpoint. (Godin had been a guest investigator at IfM, Kiel). 
In the 1980s, following the launch of radar altimeter satellites the research of our institutes (IfM Kiel that became GEOMAR and UK NIO that became the Institute of Oceanographic Sciences and then the Southampton Oceanography Centre) turned towards planning for the World Ocean Circulation Experiment (WOCE). WOCE was to take a global perspective and would make observations between 1990 and 1998 .

IfM moved focus from mesoscale eddy research to WOCE sites in the South Atlantic. Basin-wide hydrographic sections, repeat surveys, and more arrays of moored current meters supplemented by eddy-resolving RAFOS floats were the main tools for its the large-scale field work. The UK foci in WOCE were the North Atlantic and Southern Ocean occupying trans-oceanic sections and deploying moorings as a means of quantifying the global circulation (Haine et al., 1998), (Cunningham et al., 2003, 2007) and studying the gyre-scale circulation (Read, Gould, 1992).

The main results of WOCE were published in two comprehensive books edited by Siedler, Church and Gould (2001) after the final WOCE conference in Halifax in 1998 and taking a wider perspective (Siedler et al., 2013). The breakup of the USSR and its economic consequences limited Russian ship-based involvement in WOCE but it was a pleasure to work again with Vladimir Kamenkovich, Michael Koshlyakov and especially for John Gould to visit Moscow in 1990 and 1996 when he was able to meet Konstantin Sabinin for the first time.

Our understanding of, and ability to observe, the oceans has advance in ways that few of us could have imagined in 1970. We can routinely monitor not just the oceans' surface but it interior thanks to robotic Argo floats (Roemmich et al., 2019), derivatives from Swallow's neutrally buoyant floats. The assimilation of these data and satellite observations allow us all to see the global-scale ocean routinely.

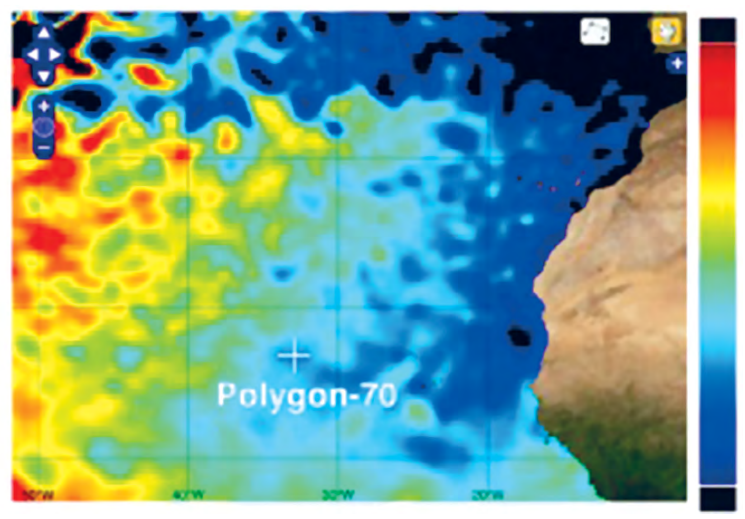

Figure 13. Sea surface height in May 2020 showing mesoscale structures and the position of the Polygon-70 moored array. Produced from https://resources.marine.copernicus.eu/

Closing remark. It was at the WOCE workshop in Zvenigorod (west of Moscow) in January 1990 that Nikolai Maximenko, a researcher at the P.P. Shirshov Institute, approached John Gould. He told him of his study of the effects of mooring motion on current meter recordings during Megapolygon-87 (Maxcimenko, 1992). And so, the story had come full circle. 
Gould W. John, Zenk W.

Acknowledgements: We thank Dr Viktor Neiman for the invitation to contribute to this special volume. We also thank former members of SCOR WG21, Ferris Webster and Gerold Siedler, for their comments on this manuscript. Sadly some of our fellow shipmates and members of SCOR WG 21 have died: Konstantin Fedorov (1927-1988), Nick Fofonoff (1929-2003), Eberhard Francke (1938-1988), Bob Heinmiller (1940-2005), Boris Shekhvatov (1924-2011) and John Swallow (1923-1994). We dedicate this paper to their memory.

\section{References}

Armi, L. and W. Zenk. Large lenses of highly saline Mediterranean water. Journal of Physical Oceanography, 1984, Vol. 14, pp. 1560-1576.

Brekhovskikh, L.M., et.al. Some results of a hydrophysical experiment in a polygon in the Tropical Atlantic. Isv. Akad. Nauk SSSR, Fizika atmosfery i okeana, 1971, Vol. 7, No. 5, pp. 511-527.

Crease, $J$. Velocity measurements in the deep water of the western North Atlantic, summary. Journal of Geophysical Research, 1962, Vol. 67, pp. 3173-3176.

Cunningham, S.A., S.G. Alderson, B.A. King, and M.A. Brandon. Transport and variability of the Antarctic Circumpolar Current in Drake Passage. Journal of Geophysical Research, 2003, Vol. 108, (C5), 8084, doi: 10.1029/2001 JC001147.

Cunningham, S.A., T. Kanzow, D. Rayner, M.O. Baringer, W.E. Johns, J. Marotzke, H.R. Longworth, E.M. Grant, J.M. Hirsch, L.M. Beal, C.S. Meinen, and H.L. Bryden. Temporal variability of the Atlantic Meridional Overturning Circulation at 26.5 N. Science, 2007, Vol. 317, No. 5840, pp. 935-938.

Dickson, R.R., W.J. Gould, P.A. Garbutt \& P.D. Killworth. A seasonal signal in ocean currents to abyssal depths. Nature, 1982, Vol. 295, pp. 193-198.

Dickson, R.R., W.J. Gould, T.J. Muller \& C. Maillard. Estimates of the mean circulation in the deep $(>2000 \mathrm{~m})$ layer of the Eastern North Atlantic. Progress in Oceanography, 1985, Vol. 14, pp. 103-127.

Fedorov, K.N. The thermohaline finestructure of the ocean. Leningrad: Gidrometeoizdat, 1976, 184 p., (In Russian), translated by Pergamon Press, Oxford, 1978, 170 p.

Francke, E., D. Böhl, U. Lass, F. Möckel, and K. Voigt. Bericht über internationale Experimente zum Vergleich von Geräten zur Messung der Meeresströmung. Beiträge zur Meereskunde, 1977, Vol. 39, pp. 103-106.

Freeland, H.J. and W.J. Gould. Objective analysis of meso-scale ocean circulation features. Deep Sea Research and Oceanographic Abstracts, 1976, Vol. 23, No. 10, pp. 915-918.

Gould, W.J. Physical Oceanography of the Azores Front. Progress in Oceanography, 1985, Vol. 14, pp. 167-190.

Gould, W.J. and E. Sambuco. The effect of mooring type on measured values of ocean currents. Deep-Sea Research, 1974, Vol. 22, No. 1, pp. 55-62.

Haine, T.W.N., A.J. Watson, M.I. Liddicioat, and R.R. Dickson. The flow of Antarctic bottom water to the southwest Indian Ocean estimated using CFCs. Journal of Geophysical Research, 1998, Vol. 103(C12), pp. 27,637-27,653.

Heinmiller, R.H. The Woods Hole Buoy Project moorings - 1960 through 1974. WHOI Technical Report 76-53, Woods Hole Oceanographic Institution, Woods Hole, Massachusetts, 1976, $73 \mathrm{pp}$. 
Hydrogräphisches Amt der Admiralität. Die Forschungsreise der SMS "Gazelle" in den Jahren 1874 bis 1876. 5 Volumes. Berlin: Ernst Siegfried Mittler und Sohn., 1888. (Online at https://www.biodiversitylibrary.org/bibliograph/984\#/summary).

Koshlyakov, M.N. and A.S. Monin. Synoptic eddies in the ocean. Annual Review of Earth and Planetary Sciences, 1978, Vol. 6, pp. 495-523.

Kubany, S.K. Musings on Communications within the Ocean Research Community. Oceanography, September, 2008, Vol. 21, No. 3, pp. 26-37, (ISSN 1042-8275).

Löptien, U. and H. Dietze. Sea ice in the Baltic Sea - revisiting BASIS ice, a historical data set covering the period 1960/1961-1978/1979. Earth Syst. Sci. Data, 2014, Vol. 6, pp. 367374.

Maximenko, N.A. Effect of surface waves on current meter velocity measurements. Experiment Megapolygon (Ed.: Yu.A. Ivanov), 1992, pp. 304-318.

Mikhin, D.Y., O.A. Godin, O. Boebel, and W. Zenk. Simulations of acoustic imprints of meddies in the Iberian Basin: Toward acoustic detection of meddies. Journal of Atmospheric and Oceanic Technology, 1997, Vol. 14, pp. 938-949.

Read, J.F. and W.J. Gould. Cooling and freshening of the subpolar North Atlantic Ocean since the 1960s. Nature, 1992, Vol. 360, pp. 55-57.

Richardson, W.S., P.B. Stimpson, and C.H. Wilkins. Current measurement from moored buoys. Deep-Sea Research, 1963, Vol. 10, pp. 369-388.

Roemmich, D., M.H. Alford, H. Claustre, et al. On the Future of Argo: A Global, Full-Depth, MultiDisciplinary Array. Frontiers in Marine Science, 2019, Vol. 6, https://doi.org/10.3389/ fmars.2019.00439.

Scientific Committee on Oceanic Research (SCOR). Proceedings. 1966, Vol. 2, 15 p., and Annexes.

Scientific Committee on Oceanic Research (SCOR). Proceedings. 1969, Vol. 5, No. 2, 43 p., and Annexes.

Scientific Committee on Oceanic Research (SCOR). Proceedings. 1970, Vol. 6, No. 1, 12 p., and Annexes.

Siedler, G. and W. Zenk. Variability of the thermohaline staircase. Nature, 1973, Vol. 244, pp. 11-12.

Siedler, G., J. Church, and J. Gould (Eds.). Ocean Circulation and Climate. London and San Diego: Academic Press, 2001, 715 p., ISBN 0-12-641351-7.

Siedler, G., L. Armi, and T.J. Müller. Meddies and decadal changes at the Azores Front from 1980 to 2000. Deep-Sea Research II, 2005, Vol. 52, No. 3-4, pp. 583-604.

Siedler, G., S.M. Griffies, J. Gould, and J.A. Church (Eds.). Ocean Circulation and Climate A $20^{\text {th }}$ Century perspective. London and San Diego: Elsevier, 2013, 868 p., ISBN 978-012-391891-2.

Stommel, H., J. Meincke, and W. Zenk. New animals for the eddy zoo. Polymode News, 1977, Vol. 22, February 1977.

Swallow, J.C. A neutral - buoyancy float for measuring deep currents. Deep-Sea Research, 1955, Vol. 3, pp. 74-81.

Swallow, J.C. The "Aries" current measurements in the western North Atlantic. Philosophical Transactions of the Royal Society of London A, 1971, Vol. 270, pp. 451-460.

The MODE Group. The Mid-Ocean Dynamics Experiment. Deep-Sea Res., 1978, Vol. 25, pp. 859-910.

Thompson, C. Wyville and Murray, John. Report on the scientific results of the voyage of H.M.S. Challenger during the years 1872-76. (1882-1895). Reports available online at http:// www.19thcenturyscience.org/HMSC/HMSC-INDEX/index-linked.htm.

Zenk, W. Detection of overflow events in the Shag Rocks Passage, Scotia Sea. Science, 1981, Vol. 213, pp. 1113-1114. 
Gould W. John, Zenk W.

Annex 1

\section{SCOR WG-21 Timeline}

(Extracted from SCOR Proceedings available online at https://scor-int.org/work/ publications/)

1966 SCOR endorses formation of WG21 following recommendation of IOC Res. IV-7.

196718 April First meeting NIO Wormley UK.

6 July-7 August Group meets WHOI, USA and conducts first intercomparison 16-24 July.

1968 Interim report of WHOI submitted 20 May.

1969 Meets in Dublin 25-27 Sept. to plan Kurchatov Experiment. Report of first Intercomparison published 12/12/1969.

UNESCO Technical Paper in Marine Science. No. 11.

1970 Second intercomparison during Polygon-70. 20 March-3 April.

Mid-December, https://scor-int.org/work/publications/ data analysis at WHOI.

1971 August Meets during IUGG Assembly in Moscow.

1972 Third intercomparison WHOI August.

1974 At SCOR meeting in Guayaquil in December. Decision is taken to wind up WG21.

Second Intercomparison Report Published 27/5/1974.

UNESCO Technical Paper in Marine Science. No. 17.

1976 Third Intercomparison Report Published 12/4/1976.

UNESCO Technical Paper in Marine Science. No. 23. 
Океанологические исследования. 2020. Том 48. № 3. С. 31-53

\title{
ИТЕРКАЛИБРОВКА ЗАПИСЕЙ ИЗМЕРИТЕЛЕЙ ТЕЧЕНИЙ, ВЫПОЛНЕННАЯ 21-Й РАБОЧЕЙ ГРУППОЙ SCOR В 7 РЕЙСЕ НИС «АКАДЕМИК КУРЧАТОВ» - 50 ЛЕТ СПУСТЯ
}

\author{
Гоулд В. Джон ${ }^{1}$, Ценк В. ${ }^{2}$ \\ ${ }^{1}$ Почетный член Национального иентра океанографии, Саутгемптон, SOI4 3ZH, \\ Великобритания, e-mail:wjg@noc.ac.uk \\ ${ }^{2}$ Старший научный сотрудник Центра океанологических исследований ГЕОМАР \\ им. Гельмгольиа, Düsternbrooker Weg 20, 24105 Киль, Германия, \\ e-mail:wzenk@geomar.de
}

Статья поступила в редакцию 25.06.2020, одобрена к печати 26.10.2020.

\begin{abstract}
В статье описывается деятельность международной рабочей группы научного комитета по исследованию океана - Scientific Committee for Oceanic Research (SCOR)'s Working Group 21 (WG21), которая провела взаимные сравнения заякоренных измерителей течений в конце 1960-х - начале 1970-х годов. В статье особое внимание уделяется участию рабочей группы WG21 в 7-м рейсе НИС «Академик Курчатов» и ее участию в новаторской программе Полигон-70.
\end{abstract}

Ключевые слова: измеритель течений, заякоренный буй, Научный комитет по исследованию океана, SCOR, WG21, программа Полигон-70

Благодарности. Авторы благодарны Виктору Нейману за приглашение внести свой вклад в этот специальный выпуск журнала «Океанологические исследования». Мы также благодарим бывших членов SCOR WG21, Ферриса Вебстера и Герольда Зидлера за их комментарии к этой рукописи. К сожалению, некоторые из наших товарищей по команде и члены SCOR WG 21 уже ушли от нас: Константин Федоров (1927-1988), Ник Фофонов (1929-2003), Эберхард Франке (1938-1988), Боб Хейнмиллер (1940-2005), Борис Шехватов (1924-2011) и Джон Суоллоу (1923-1994). Мы посвящаем эту статью их памяти.

\section{Литература}

Armi L., Zenk W. Large lenses of highly saline Mediterranean water // Journal of Physical Oceanography. 1984. Vol. 14. P. 1560-1576.

Brekhovskih L.M. et.al. Some results of a hydrophysical experiment in a polygon in the Tropical Atlantic // Isv. Akad. Nauk SSSR, Fizika atmosfery i okeana. 1971. Vol. 7. No. 5. P. 511527.

Crease J. Velocity measurements in the deep water of the western North Atlantic, summary // Journal of Geophysical Research. 1962. Vol. 67. P. 3173-3176.

Cunningham S.A., Alderson S.G., King B.A., Brandon M.A. Transport and variability of the Antarctic Circumpolar Current in Drake Passage // Journal of Geophysical Research. 2003. Vol. 108. (C5). 8084. DOI: 10.1029/2001JC001147.

Cunningham S.A., Kanzow T., Rayner D., Baringer M.O., Johns W.E., Marotzke J., Longworth H.R., Grant E.M., Hirsch J.M., Beal L.M., Meinen C.S., Bryden H.L. Temporal variability 
Гоулд В. Джон, Ценк В.

of the Atlantic Meridional Overturning Circulation at 26.5 $\mathrm{N} / /$ Science. 2007. Vol. 317. No. 5840. P. 935-938.

Dickson R.R., Gould W.J., Garbutt P.A., Killworth P.D. A seasonal signal in ocean currents to abyssal depths // Nature. 1982. Vol. 295. P. 193-198.

Dickson R.R., Gould W.J., Muller T.J., Maillard C. Estimates of the mean circulation in the deep (>2000 m) layer of the Eastern North Atlantic // Progress in Oceanography. 1985. Vol. 14. P. $103-127$.

Fedorov K.N. The thermohaline finestructure of the ocean. Leningrad: Gidrometeoizdat, 1976. 184 p. (In Russian), translated by: Oxford: Pergamon Press, 1978. 170 p.

Francke E., Böhl D., Lass U., Möckel F., Voigt K. Bericht über internationale Experimente zum Vergleich von Geräten zur Messung der Meeresströmung // Beiträge zur Meereskunde. 1977. Vol. 39. P. 103-106.

Freeland H.J., Gould W.J. Objective analysis of meso-scale ocean circulation features // Deep Sea Research and Oceanographic Abstracts. 1976. Vol. 23. No. 10. P. 915-918.

Gould W.J. Physical Oceanography of the Azores Front // Progress in Oceanography. 1985. Vol. 14. P. 167-190.

Gould W.J., Sambuco E. The effect of mooring type on measured values of ocean currents // Deep-Sea Research. 1974. Vol. 22. No. 1. P. 55-62.

Haine T.W.N., Watson A.J., Liddicioat M.I., Dickson R.R. The flow of Antarctic bottom water to the southwest Indian Ocean estimated using CFCs // Journal of Geophysical Research. 1998. Vol. 103(C12). P. 27,637-27,653.

Heinmiller R.H. The Woods Hole Buoy Project moorings - 1960 through 1974. WHOI Technical Report 76-53. Massachusetts: Woods Hole Oceanographic Institution, Woods Hole, 1976. 73 p.

Hydrogräphisches Amt der Admiralität. Die Forschungsreise der SMS "Gazelle" in den Jahren 1874 bis 1876. 5 Volumes. Berlin: Ernst Siegfried Mittler und Sohn., 1888. (Online at https://www.biodiversitylibrary.org/bibliograph/984\#/summary).

Koshlyakov M.N., Monin A.S. Synoptic eddies in the ocean // Annual Review of Earth and Planetary Sciences. 1978. Vol. 6. P. 495-523.

Kubany S.K. Musings on Communications within the Ocean Research Community//Oceanography. September, 2008. Vol. 21. No. 3. P. 26-37. (ISSN 1042-8275).

Löptien U., Dietze H. Sea ice in the Baltic Sea - revisiting BASIS ice, a historical data set covering the period 1960/1961-1978/1979 // Earth Syst. Sci. Data. 2014. Vol. 6. P. 367-374.

Maximenko N.A. Effect of surface waves on current meter velocity measurements // Experiment Megapolygon (Ed.: Yu.A. Ivanov). 1992. P. 304-318.

Mikhin D.Y., Godin O.A., Boebel O., Zenk W. Simulations of acoustic imprints of meddies in the Iberian Basin: Toward acoustic detection of meddies // Journal of Atmospheric and Oceanic Technology. 1997. Vol. 14. P. 938-949.

Read J.F., Gould W.J. Cooling and freshening of the subpolar North Atlantic Ocean since the 1960s // Nature. 1992. Vol. 360. P. 55-57.

Richardson W.S., Stimpson P.B., Wilkins C.H. Current measurement from moored buoys // DeepSea Research. 1963. Vol. 10. P. 369-388.

Roemmich D., Alford M.H., Claustre H., et. al. On the Future of Argo: A Global, Full-Depth, MultiDisciplinary Array // Frontiers in Marine Science. 2019. Vol. 6. https://doi.org/10.3389/ fmars.2019.00439.

Scientific Committee on Oceanic Research (SCOR) // Procedings. 1966. Vol. 2. 15 p., and Annexes.

Scientific Committee on Oceanic Research (SCOR) // Procedings. 1969. Vol. 5. No. 2. 43 p., and Annexes. 
Scientific Committee on Oceanic Research (SCOR) // Procedings. 1970. Vol. 6. No. 1. 12 p., and Annexes.

Siedler G., Zenk W. Variability of the thermohaline staircase // Nature. 1973. Vol. 244. P. 11-12.

Siedler G., Church J., Gould J. (Eds.). Ocean Circulation and Climate. London and San Diego: Academic Press, 2001. 715 p. ISBN 0-12-641351-7.

Siedler G., Armi L., Müller T.J. Meddies and decadal changes at the Azores Front from 1980 to 2000 // Deep-Sea Research II. 2005. Vol. 52. No. 3-4. P. 583-604.

Siedler G., Griffies S.M., Gould J., Church J.A. (Eds.). Ocean Circulation and Climate - A $20^{\text {th }}$ Century perspective. London and San Diego: Elsevier, 2013. 868 p. ISBN 978-0-12391891-2.

Stommel H., Meincke J., Zenk W. New animals for the eddy zoo // Polymode News. 1977. Vol. 22. February 1977.

Swallow J.C. A neutral - buoyancy float for measuring deep currents // Deep-Sea Research. 1955. Vol. 3. P. 74-81.

Swallow J.C. The "Aries" current measurements in the western North Atlantic // Philosophical Transactions of the Royal Society of London A. 1971. Vol. 270. P. 451-460.

The MODE Group. The Mid-Ocean Dynamics Experiment // Deep-Sea Res. 1978. Vol. 25. P. 859-910.

Thompson C. Wyville, Murray John. Report on the scientific results of the voyage of H.M.S. Challenger during the years 1872-76. (1882-1895). Reports available online at http:// www.19thcenturyscience.org/HMSC/HMSC-INDEX/index-linked.htm.

Zenk W. Detection of overflow events in the Shag Rocks Passage, Scotia Sea // Science. 1981. Vol. 213. P. 1113-1114. 